\title{
A IDÉIA DE IGUALDADE E AS AÇÕES AFIRMATIVAS
}

\section{PAULO DAFLON BARROZO}

A espécie jamais possuiu uma consciência aguda e acurada do que está em jogo. Isso não obstante, a modernidade tem testemunhado o desenvolvimento de um conjunto de ideais e programas emancipatórios cujo conteúdo e possível direção trazem consigo a até então mais promissora circunstância para um vislumbre do drama que indivíduos e a humanidade como tal protagonizam. Entretanto, o caráter moral, destino político, expressão jurídica e conseqüências sociais desses ideais e programas permanecem, além de incompletos, profundamente vulneráveis e em larga medida contestados. Este artigo avança os rudimentos de uma teoria constitucional da igualdade que reflete sua inserção, ao mesmo tempo como pressuposto e corolário, em dois desses ideais emancipatórios de forma de vida coletiva o republicanismo e a democracia - tal como aqui definidos. E na medida em que enfrenta a tarefa da especificação e do detalhamento de ideais emancipatórios o artigo toma posição inequívoca no conflito sobre esses ideais.

Como ideal para e como caráter das instituições políticas, tanto a democracia quanto a república remontam à Antigüidade1. Após séculos de adormecimento, o republicanismo, agora quase sempre desacompanhado de democracia, foi novamente objeto de atenção intelectual e experimentação política concreta no Renascimento ${ }^{2}$. Em ambos os períodos, o

\footnotetext{
${ }^{1}$ Aristóteles oferece o mais interessante estudo clássico da experiência grega. Para as formas mistas inspiradas na experiência romana Políbio e Cícero são as fontes mais relevantes.

${ }^{2}$ Leia-se Maquiavel e James Harington como fontes contemporâneas de pensamento republicano. O seguinte estudo do republicanismo renascentista é especialmente útil: J. G. A. Pocock: The Maquiavellian Moment: Florentine Political Thought and the Atlantic Republican Tradition. Princeton, Princeton University Press, 1975. Para análise da história intelectual relevante para o republicanismo da Alta Idade Média e Renascimento veja-se Quentin Skinner: The Foundations of Modern Political Thought. Cambridge, Cambridge University Press, 1978.
} 
conteúdo do ideal republicano-democrático resumia-se na idéia de independência externa das comunidades políticas, garantida através de um elenco de virtudes cívicas que favoreciam o patriotismo e o militarismo, e na idéia de gestão participativa por uma elite política em oligopólio do status de cidadania. O capítulo seguinte dessa história consubstanciou-se no ataque moderno à sinergia entre o Estado autoritário e patrimonial e a sociedade civil estamental. Condensando-se nessa oposição à sociedade do Ancient Régime, os ideais de democracia e república vieram a sustentarse na liberdade, na igualdade e na solidariedade geral como valores intensamente interligados e extensamente sobrepostos ${ }^{3}$ que como tais entraram definitivamente em praça pública com as revoluções do século XVIII. É para o significado profundo da mudança moderna no conteúdo dos ideais de república e democracia que se precisa agora atentar.

(I) Na modernidade a aspiração à liberdade assumiu uma dupla dimensão: política e individual. Em sua dimensão política a liberdade é refletida, tal como entre os antigos, no ideal de independência e autogoverno da comunidade política a que se pertence, enquanto na dimensão individual, esta moderna por excelência, ela torna-se mais claramente manifesta na disponibilidade, para cada membro da comunidade política, das condições para embarcar em projetos, em larga medida idiossincráticos, de Bildung. (II) Já a igualdade vem recebendo titubeante especificação, problema que o artigo ambiciona encarar. Basta por agora mencionar algumas das características mais notáveis do tipo de sociedade contra a qual o ideal de igualdade ganhou força: a sociedade estamental. Nas sociedades estamentais do Ancient Régime os vários estamentos eram estanques, onde oportunidades de mobilidade individual transestamental eram quando muito escassas; esses estamentos estanques eram ainda hierarquizados, hierarquia esta que se refletia no fato social da diferenciada determinação, em função dos estamentos, dos prestígio e autoridade pessoal e de classe, da distribuição de bens públicos, do acesso a oportunidades sociais e das posições de poder político e influência social; o pertencimento final de cada indivíduo a um dado estamento era quase invariavelmente função da sua posição estamental ao nascimento - ela chegava ao fim de sua vida olhando o mesmo horizonte social que olhara quando a ela chegara; e, por fim, a sociedade estamental era legitimada por formas de representação e

3 "No Estado atual da civilização, tirar liberdade é fazer desiguais os não-livres, tirar igualdade é restringir a liberdade." (Pontes de Miranda: Comentários á Constituição de 1946. Tomo IV. Rio de Janeiro, Borsoi, 1960. p. 283). 
discurso que vigoravam em todos os estamentos. $\mathrm{O}$ levante inicial da igualdade como ideal deve ser compreendido sempre nesse contexto estamental; quer dizer, no âmbito do progresso moderno da hierarquização feudal para a diferenciação moderna. (III) Em contraposição à solidariedade intraestamental do Ancient Régime, a solidariedade geral ${ }^{4}$ como ideal moderno reflete a percepção - ora incisiva e generalizada, como em momentos de crise ou transformação social orquestrada, ora delgada e seletiva, como em momentos de elevada rotinização da vida social e tepidez moral - de compartilhamento de um mesmo destino. A idéia central aqui é a de que o que está por vir virá para todos, sem que haja grupos suficientemente protegidos das incertezas de um futuro comum.

Poder-se-ia perguntar da razão pela qual a liberdade, a igualdade e a solidariedade geral seriam considerados valores; ou da razão para sustentar-se os ideais de democracia e república como formas de organização da vida coletiva baseada nesses valores; ou ainda o que há de propriamente emancipatório nesses ideais e valores. Para essas questões várias respostas foram oferecidas, daquelas baseadas na eficiência dos agregados humanos assim definidos para enfrentar o processo evolutivo-seletivo de sociedades humanas, até outras baseadas numa versão qualquer de natureza humana e da correspectiva exigência de uma forma de organização da vida coletiva que permitisse uma mais autêntica vida individual ou da espécie como tal. O que parece ser fundamental, entretanto, é uma idéia ainda mais robusta e que toma forma apenas quando a humanidade é vista da dupla perspectiva do indivíduo e da espécie em suas promessas de dignidade e progresso: a idéia de um elenco permanentemente expansível de potenciais incandescentes da personalidade e benignos para a espécie e da exploração intensa desses potenciais por cada indivíduo, tal como são tornados disponíveis em cada época e circunstância. Que uma consciência desta idéia mais robusta não seja universal e que não seja mais profundamente imersa e amplamente disseminada na autocompreensão da espécie em tempos modernos é parte do drama e origem de muitas das tragédias da experiência humana. Mas é também o mais poderoso hierarquizador de prioridades

4 Trata-se aqui de conceito cujo critério definidor é diferente, porém paralelo, ao usado por Durkheim para capturar conceitualmente o tipo de solidariedade social próprio às formas de vida coletiva baseadas na divisão do trabalho. O paralelismo está exatamente no fato de que ambos os conceitos, o de Durkeime e o aqui proposto, apontam para o fenômeno de um destino social que é basicamente comum a todos: "Society becomes more effective in moving in concert, at the same time as each of its elements has more movements that are peculiarly its own." E. Durkheim: The Division of Labor in Society. Translated by W. D. Halls. New York, The Free Press, 1997. p. 85. 
quanto ao que fazer. Proponho então que a razão mais forte e elementar para defender formas de vida que dão realidade aos valores da igualdade, da liberdade e da solidariedade geral está na relação entre a manifestação concreta desses valores e um sempre expansível horizonte de potenciais humanos benignos. E no contexto dos programas emancipatórios - emancipatórios exatamente dos potenciais humanos para o bem - modernos a república democrática aparece como a forma de partilhamento coletivo da experiência da vida que até este momento mais integralmente expressou, em instituições e práticas, aqueles valores ${ }^{5}$. As promessas de dignidade humana são cumpridas ou não no ágon da expansão e da fruição dos potenciais humanos, enquanto a combinação de patrimonialismo estatal, autoritarismo político e rígida estratificação social que caracterizava a sociedade européia medieval e tantas outras sociedades contemporâneas são fantasma a constantemente nos assombrar a todos.

Potenciais humanos são, por outro lado e a um só tempo, hospedeiros e hóspedes de formas de vida coletiva; e formas de vida são feitas não só de ideais e valores mas também dos infindáveis arranjos onde instituições, modulações ideativas e práticas encontram-se a cada momento de cada dia. Assim - como ademais é o caso de todo princípio integrante de ideais de formas de vida coletiva - liberdade, igualdade e solidariedade também permaneceriam ficcionais não fossem traduzidos pelo direito em especificidade e generalidade. $\mathrm{O}$ primeiro grande movimento jurídico moderno, o Constitucionalismo, ao buscar instituir o modus vivendi republicano-democrático mostrou o nível de amadurecimento relativo da consciência moderna da necessidade do Direito como medium entre ideais e vida ordinária. Porém, tanto na etapa inicial das Declarações de Direitos como na seguinte de regulamentação do Estado e de suas relações com a sociedade civil, o Constitucionalismo, aspiracionalmente instituidor dos ideais republicano e democrático, falhou em gerar uma teoria constitucional do ideal da igualdade que ao mesmo tempo o especificasse, concretizasse e universalizasse. Essa falha enseja a tarefa a que este artigo se propõe: colaborar na formulação de uma tal teoria.

$\mathrm{O}$ artigo, pelas posições que toma e pelo modo em que as toma, assume o caráter de manifesto político. Como contexto de teste da densidade

5 Para exemplo de estudo empírico da incompatibilidade entre democracia e violações de direitos que dão mesmo que minguadamente expressão a esses valores veja-se Christian Davenport \& David A. Armstrong: "Democracy and the Violation of Human Rights: A Statistical Analysis from 1976 to 1996." 48, American Journal of Political Science, p. 538554 (2004). 
teórica, relevância ideativa e potencial operativo das idéias que defende, avança-se, no que diz respeito à questão do acesso a cursos superiores no Brasil, uma desinibida defesa do que convencionalmente veio a chamar-se ação afirmativa. Defesa que é feita na tradição do discurso constitucional a partir de uma teoria da igualdade que reflete o centro mais denso dos ideais republicanos e democráticos em política moderna. Entretanto, os contextos sociais de aplicação das exigências do princípio da igualdade e os sujeitos para os quais este é relevante são muitos, incluindo certamente a sua pertinência para arranjos coletivos além e aquém do Estado-Nação que sejam fundados sobre os ideais republicano e democrático.

A estratégia do argumento passa por desenvolver esquema analítico que permite melhor compreender, primeiro isoladas e depois em algumas de suas importantes conexões, as idéias de mérito, distribuição de bens públicos e oportunidades sociais, igualdade, desigualdade $\mathrm{e}$ discriminação. A questão fundamental a orientar a resposta teórica que se oferece é a seguinte: que tipo de igualdade os ideais republicanos e democráticos, tal como aterrissados nas formas de vida coletiva moderna conforme aqui reconstruídos, exigem como princípio regulativo e como tarefa institucional?

\section{TEORIA CONSTITUCIONAL DA IGUALDADE}

\section{A Questão da Igualdade}

Nos ideais republicano e democrático como acima reconstruídos, a igualdade, relativa por natureza, é relevante enquanto contrário da desigualdade. Dito de outra forma, o que se busca é uma igualdade seletiva cuja expressão mais acurada está na vedação de determinados tipos ou intensidades de desigualdade. Por exemplo, uma estrita igualdade material jamais integrou o ideário republicano-democrático como veio a integrar a agenda dos partidos socialistas e dos movimentos de trabalhadores industriais no século $\mathrm{XIX}^{6}$. De outro lado, o revival contemporâneo do republicanismo tende a interpretar a tradição republicana dando ênfase a seus

${ }^{6}$ Para uma visão do pensamento social e da estratégia política desses movimentos no seu contexto mais exemplar, veja-se Frank Mecklenburg \& Manfred Stassen (Eds.): German Essays on Socialism in the Nineteenth Century: Theory, History, and Political Organization, 18441914. New York, Continuum, 1990. 
aspectos cívicos ${ }^{7}$. Central, no entanto, ao ideário republicano moderno como agenda emancipadora e ponto-de-vista crítico foi sua crítica à sociedade estamental, ao estado patrimonial e aos padrões espúrios de distribuição de bens públicos e oportunidades sociais no Ancient Régime. Com o ideal de autogoverno as coisas não foram diferentes: a democracia moderna não encampou quer a estrita igualdade material quer o claustrocivismo - no qual pouco ou nada resta ao patriotismo como virtude própria do nacionalismo depois que dele se extrai o condicionamento social como elementos integrantes de seu ideário. A organização democrática da vida coletiva deveria ser ordenada com base na participação mais ou menos intensa e mais ou menos remota, porém em bases formalmente iguais, dos membros da sociedade. Pressuposto moral e corolário lógico desses ideais sempre foram a liberdade coletiva e individual, a igualdade de status moral $^{8}$ e jurídico e o dever de solidariedade geral em face da organização da vida comum e das intempéries sociais. E como nas repúblicas democráticas a igualdade como valor é realmente mais visível sob a forma de sua imagem invertida, em seu Rights of Man de 1791 Thomas Paine expressou assim as bases libertárias e igualitárias do republicanismo e da democracia modernas contra o pano de fundo da sociedade feudal e suas instituições políticas:

When we survey the wretched condition of man under the monarchical and hereditary systems of Government [...] it becomes evident that those systems are bad, and that a general revolution in the principle and construction of Governments is necessary. [...W]hat we now see in the world, from the Revolutions of America and France, are a renovation of the natural order of things, a system of principles as universal as truth and the existence of man, and combining moral with political happiness and national prosperity. [...M]en are born and always continue free, and equal in respect of their rights. Civil distinc tions, therefore, can be founded only on public utility. ${ }^{9}$

\footnotetext{
7 Para versão jurídica do ideal republicano em sociedades pós-cívicas e pluralistas, veja-se Frank Michelman: "Law's Republic.” 97, The Yale Law Journal, páginas 1493-1537 (1988). Para formulação contemporânea geral do ideal, veja-se Philip Pettit: Republicanism: A Theory of Freedom and Government. Oxford, Oxford University Press, 1999.

8 Tal como influentemente retratada por Tocqueville nos Livro I, Parte 2 e Livro II, Partes 2, 3 e 4 de Democracia na América.

9 Thomas Paine: Rights of Man. In Paine: Collected Writings. New York, Literary Classics of the United States, 1995. p. 536-537.
} 
Escrevendo um século depois, João Barbalho, ao comentar a primeira constituição pós-imperial do Brasil, proclamava com a autoridade da ideologia dominate do dia que

[A] desigualdade, além de injusta e injurídica, é impolítica. Em que fundamento se faria repousar uma organização política, dando mais direitos, mais garantias, mais vantagens, a uns do que a outros membros da mesma comunhão? [...D]e todas as formas de governo é a república a mais própria para o domínio da igualdade, a única compatível com ela. 10

Porém, e não obstante sua proeminência na formação da cultura, instituições e práticas sociais modernas, a idéia de igualdade está ainda por receber adequada especificação ${ }^{11}$ e respectiva tradução jurídica. Tal como

10 João U. C. Barbalho: Constituição Federal Brazileira: Comentários. Rio de Janeiro, Typographia da Companhia litho-typographia em Sapopemba, 1902. p. 303-304.

11 Além dos textos nas demais notas deste artigo, os seguintes podem ser consultados com proveito a respeito do tratamento contemporâneo da igualdade como conceito: Bernard Williams: "The Idea of Equality?" em P. Laslett \& W. G. Runciman (Eds.): Philosophy, Politics, and Society (second series). Oxford, Blackwell, 1969; Ralf Dahrendorf: "On the Origin of Social Inequality" em P. Laslett and W. G. Runciman, op. cit.; Steven Lukes: "Socialims and Equality" em seu Essays in Social Theory. New York, Columbia University Press, 1977; os capítulos II e IV de John Rawls: A Theory of Justice. Cambridge, Harvard UP, 1999; Friedrich A. von Hayek: The Constitution of Liberty. Chicago, University of Chicago Press, 1960; Derek Parfit: "Equality and Priority." 10, Ratio, páginas 202-221 (1997); Michael Walzer: Spheres of Justice. New York, Basic Books, 1983; o Capítulo 9 de Joseph Raz: The Morality of Freedom. Oxford, OUP, 1988; Douglas Rae: Equalities. Cambridge, Harvard UP, 1981; John Roemer: Equality of Opportunity. Cambridge, Harvard University Press, 1998; Amartya Sen: Development as Freedom. New York, Knopf, 1999; Amartya Sen: "Equality of What?" The Tanner Lecture on Human Value, Stanford University, 1979. (http:// www.tannerlectures.utah.edu /lectures/ sen80.pdf); Amartya Sen: Inequality Reexamined. Cambridge, Harvard University Press, 1992; Gerald A. Cohen: "On The Currency of Egalitarian Justice.” 99, Ethics, páginas 906-944 (1989); Gerald A. Cohen: If You're an Egalitarian, How Come You're so Rich? Cambridge, Harvard UP, 2000; Kent Greenwalt: "How Empty is the Idea of Equality?" 83, Columbia Law Review, páginas 1167-1185 (1983); a Parte II de Philippe van Parijs: Qu'est-ce qu'une société juste? Paris, Seuil, 1991; Philippe van Parijs: Real Freedom for All: What (if Anything) Can Justify Capitalism? Oxford, Oxford University Press, 1995; Joshua Cohen: "Democratic Equality." 99, Ethics, páginas 727-751 (1989); Harry Frankfurt: "Equality as a Moral Ideal." 98, Ethics, páginas 21-42 (1987); Thomas Nagel: Equality and Partiality. Oxford, Oxford University Press, 1991; Peter Westen: Speaking Equality. Princeton, Princeton University Press, 1990. As seguintes coletâneas trazem outros textos de interesse: Mattthew Clayton e Andrew Williams (Eds.): The Ideal of Equality. New York, St. Martin's Press, 2000; J. R. Pennock \& J. W. Chapman (Eds.): Nomos IX: Equality. New York, Atherton, 1967; Louis Pojman e Robert Westmoreland (Eds.): Equality: Selected Readings. Oxford, Oxford University Press, 1997. 
hodierna e hegemonicamente concebida e refletida no direito das repúblicas democráticas, a idéia de igualdade é ainda refém de um formalismo original que a resume à igualdade de status entre sujeitos, livre-volentes, de regras jurídicas e morais. Essa igualdade de status entre sujeitos normativos tende a cristalizar os padrões distributivos das sociedades as quais cobrem com sua matriz jurídica. ${ }^{12}$ Essa tendência pode ser explicada pela combinação de duas causas: de um lado, a manifesta inadequação da igualdade de status para surpreender, diagnosticar e indicar medidas corretivas de padrões distributivos espúrios; de outro, a sua correlativa tradução, através de sua acoplação histórica com discursos prestigiosos sobre o entitulamento da subjetividade moral-jurídica, numa concepção especial de um elenco particular de direitos da personalidade e patrimoniais. Como quer que seja, o efeito de cristalização de padrões distributivos - com efeito cumulativo transgeracional através da correia-de-transmissão da família contraria os ideais de democracia e república tal como aqui reconstruídos.

A carência da especificação conceitual e da tradução da igualdade tem impedido conseqüente e consistente orientação das formas de vida republicanas e democráticas à luz da igualdade como valor. A intensificada necessidade de uma tradução jurídica de uma concepção mais clara da igualdade como ideal não deve, ademais, a ninguém surpreender: ao direito, como instituição e como forma de pensamento, cabe às tarefas de traduzir e articular, a um só tempo em especificidade quanto a seu conteúdo e em generalidade quanto à sua abrangência, os ideais sobre os quais formas de vida são erigidas. No discurso jurídico são também lavradas críticas e reconstruções dessas mesmas formas de vida, e assim o é mais e mais graças à sua capacidade de intermediação entre o ideal e o mundano.

Este artigo não subestima a tarefa que assume. Como conceito, a igualdade compartilha com tantos outros conceitos uma característica especial e freqüentemente atordoadora: é, no que tange a seu significado, carregada de um peso ao mesmo tempo ideativo e empírico, prescritivo e descritivo. A igualdade é, portanto, moral, jurídico e politicamente colorida, enquanto clamando também competência semântica empírico-descritiva. Sendo assim, a igualdade pode ser axiologicamente contestada ou empiricamente refutada, ou ambos. O maior e mais recorrente problema na análise conceitual da igualdade está assim na assimilação de suas significações ideativas e sócio fenomenológicas, o que leva a uma situação de

12 Do ponto de vista jurídico, veja-se o insight de Robert Hale em seu "Coercion and Distribution in a Supposedly Noncoercive State.” 38 Political Science Quarterly 470 (1923). 
infundadas ora naturalizações ora historicizações da desigualdade. A ambição confessada deste artigo é lançar as fundações de uma reconstrução da idéia de igualdade de modo suficientemente analítico para que o exercício reconstrutivo possa, escapando como pode desses problemas conceituais, produzir uma moldura conceitual útil na condução da experiência constitucional de comunidades políticas que abracem os ideais de república e democracia tal como definidos na seção anterior.

\subsection{A Idéia de Igualdade na Experiência Constitucional Americana}

A mais extensa e profunda experiência constitucional democrática e republicana tem sido a americana, onde a Suprema Corte vem desenvolvendo desde a adoção da XIV emenda constitucional em 1868 - o fragmento da XIV emenda que serviu de ponto de partida para a doutrina constitucional da igualdade diz o seguinte: "No State shall [...] deny to any person within its jurisdiction the equal protection of the laws" - doutrina sobre a natureza e conseqüências do princípio da igualdade perante a lei ${ }^{13}$. A mesma doutrina aplica-se também à União Federal através da construção interpretativa que veio a se fazer do princípio do devido processo legal substantivo da $\mathrm{V}$ emenda. Note-se, porém, que o princípio vem em forma de uma vedação constitucional à ação do Estado que viole a igualdade legal. Trata-se, no constitucionalismo americano, de princípio que só abarca casos onde o Estado possa, direta ou indiretamente, ser apontado como agente na violação da igualdade legal.

O início dessa história doutrinária caracterizou-se, no caso Plessy de 1896, pela estrita aplicação formalista - entendida como equivalência do tratamento legislativo - e passiva - via controle provocado da validade constitucional de normas infraconstitucionais - do princípio da igualdade à condição do negro então recém-liberto e de seus descendentes. Enquanto um formalismo passivo rústico pode ser claramente detectado no voto vencedor - "the object of the Amendment was undoubtedly to enforce the absolute equality of the two races before the law, but in the nature of things it could not have been intended to abolish distinctions based upon color, or to enforce social, as distinguisehd from political equality" - foi a versão desse formalismo passivo elaborada pelo juiz Harlan em sua famosa

13 Para acesso em língüa portuguesa, veja-se Joaquim Barbosa Gomes: Ação Afirmativa e Princípio Constitucional da Igualdade - O Direito como Instrumento de Transformação Social. A Experiência Constitucional Americana. Rio de Janeiro, Renovar, 2001. 
dissensão - "our constitution is color-blind, and neither knows nor tolerates classes among citizens" - que veio a governar, até o caso Brown de 1954, a concepção de igualdade na experiência americana.

$\mathrm{O}$ atual estágio da evolução constitucional americana procura identificar "valores fundamentais" e potenciais grupos recorrentemente vitimados que dariam então o conteúdo da igualdade para fins de equal protection. Paralelamente, desenvolveu-se uma tímida e truncada sensibilidade para fatores estruturais ou extra-pessoais geradores ou reforçadores de desigualdades consideradas injustificáveis. Tais fatores operariam uma discriminação de facto a despeito da constatação de que a ação ou omissão estatal apontada como responsável não apresentasse, prima facie, injustificada discriminação. Na linguagem do caso Griggs, de 1971, tem-se o seguinte: "[O Civil Rights Act de 1964] proscribes not only overt discrimination but also practices that are fair in form, but discriminatory in operation." Hoje, toda vez que uma legislação é examinada sob a luz da equal protection um teste de constitucionalidade baseado na natureza do valor ou bem afetado e no grau de suspeitabilidade da classificação de indivíduos ou grupos porventura feita na legislação é disparado. A partir da década de 1960 a Suprema Corte desenvolveu um esquema de três níveis de escrutínio constitucional de legislação com vistas à cláusula de igualdade perante à lei, de acordo com esses bens e valores e os grupos atingidos. No primeiro nível, onde os valores e bens afetados não são considerados fundamentais ou a classificação de indivíduos ou grupos não é "suspeita", basta que o legislador tenha agido de modo racional ${ }^{14}$ quanto aos meios a atingir fim legítimo para que a lei suspeita de violação da cláusula de igualdade passe o teste constitucional. No nível seguinte, a finalidade da iniciativa legislativa deve ser importante e os meios a atingi-la substancialmente relevantes, tendo em vista um também maior grau de fundamentalidade do valor ou bem ou da suspeitabilidade da classificação de indivíduos ou grupos usada. Já o último nível requer que os meios sejam absolutamente necessários e a finalidade importantíssima toda vez que valores ou bens considerados fundamentais e indivíduos ou grupos historicamente discriminados estejam envolvidos. $\mathrm{O}$ índice de mortalidade constitucional de legislação aumenta brutalmente - de quase nenhum a quase todos - do primeiro ao último nível de escrutínio.

${ }^{14}$ Para uma análise formalista, no contexto brasileiro, do problema da constitucionalidade da discriminação legislativa entre indivíduos ou grupos à luz de sua "correlação lógica" entre meio e fim legislativo, veja-se Celso Antônio Bandeira de Mello: O Conteúdo Jurídico do Princípio da Igualdade. São Paulo, Malheiros, 1993. 
No que diz respeito à ação afirmativa, o inquietante do ponto de vista interno à prática constitucional americana sempre esteve em utilizarse classificação considerada da mais suspeita possível - cor da pele - com a finalidade de beneficiar o grupo classificado ou discriminado. $\mathrm{O}$ argumento para, em Brown, abandonar-se a postura formalista e passiva da color blindness, sem que com isso se cometesse discriminação inconstitucional, baseou-se na aferição da benignidade da intenção e finalidade da legislação ou policy constitucionalmente desafiada. Iniciativas que objetivassem ativamente promover a igualdade, onde a vigília constitucional montada sob a égide da igualdade formal não obtivera sucesso, poderiam em tese ser constitucionalmente permitidas ou mesmo exigidas. Assim é que enquanto na discriminação inconstitucional a finalidade seria (I) vedar ou tornar especialmente difícil o acesso de pessoas ou coletividades a bens e oportunidades ou (II) sustentar uma hierarquia entre indivíduos e grupos com base em valoração assimétrica de características individuais ou coletivas consideradas proeminentes, na discriminação constitucional a finalidade deveria ser a criação de um dispositivo ativa e afirmativamente equalizador para o grupo discriminado.

A prática constitucional americana progrediu, então, da aceitação da discriminação afirmativa como ação reparadora específica de efeitos específicos de discriminação maligna sobre grupos ou indivíduos específicos, para a feição atual da afirmative action. Atualmente, desde o caso Bakke em 1978, cor e etnia, entre outros fatores de classificação de grupos humanos, podem ser usados e pesados em consideração aos candidatos à admissão em curso superior, sendo entretanto vedado o emprego de cotas, ou números fixos de vagas a serem preenchidas por membros do grupo discriminado afirmativamente. O sistema Bakke sobreviveu à aplicação do terceiro nível de escrutínio constitucional donde resultou o entendimento da maioria da corte no sentido de que a finalidade de reparação ou o alcance de diversidade pedagogicamente relevante do corpo de estudantes, da qual aliás todos se beneficiariam, autorizava a discriminação benígna; entretanto, o emprego de cotas não sobreviveu ao teste que requer seja o meio empregado necessário a atingir a finalidade buscada. A maioria em Bakke decidiu que a diversidade pedagogicamente solicitada poderia ser alcançada sem o emprego de cotas, apontando a política de admissão de Harvard à época como exemplo de obtenção de diversidade através de consideração e peso relativo conferidos a fatores como cor e etnia, sem o pré-comprometimento de um número fixo de vagas. 
Este artigo não tem como propósito oferecer uma crítica à experiência constitucional americana da igualdade republicana. 15 Não obstante, a moldura crítico-reflexiva oferecida abaixo, que imbrica as idéias de mérito, distribuição de bens públicos e oportunidades sociais, igualdade, desigualdade e discriminação, oferece, incidentalmente, elementos para uma crítica dessa experiência em termos de seu principal agente, dos seus critérios de seleção de vítimas de discriminação ou grupos vulneráveis a serem afirmativamente beneficiados, de sua limitada capacidade de detecção e avaliação de casos de discriminação maligna, dos argumentos que emprega em suas empreitadas justificadoras das ações afirmativas e, por fim, dos limitados corretivos que oferece.

\subsection{A Idéia de Igualdade na Experiência Constitucional Brasileira}

Comparada à experiência constitucional americana, em geral, e em relação às questões de igualdade, em particular, a experiência constitucional brasileira é primitiva, não obstante, como de costume, a fertilidade das fontes legislativas e a abundância dos exercícios doutrinários. A tradição de análise e discurso constitucional invariavelmente se satisfaz com a alegoria da razoabilidade teleológica da norma ou ação ou com uma referência - tantas vezes repetida que sua origem aristotélica tal como encampada por Rui Barbosa ficou perdida ao longo do caminho - ao princípio da isonomia. Está-se aqui, assim, sob o signo da concepção de igualdade como igualdade de status entre sujeitos normativos. Diferentemente do que ocorre nos EUA, entretanto, no sistema constitucional brasileiro a igualdade é direito oponível tanto ao Estado e seus agentes quanto, qualificadamente, a indivíduos e entidades privadas.

Uma análise da história legislativa constitucional do princípio da igualdade no Brasil mostra um largo período de monótona consistência e limitada consequiência que deságua, com a constituição de 1988, num episódio de expansão e detalhamento legislativo. O primeiro episódio

15 Para uma crítica poderosa e uma apologia competente do paradigma sobre o qual opera a equal protection adjudiction nos EUA, vejam-se, respectivamente, Roberto Mangabeira Unger: The Critical Legal Studies Movement. Capítulo 3. Cambridge, Harvard UP, 1986 ou What Should Legal Analysis Become? Páginas 83-97. New York, Verso, 1996 \& Ronald Dworkin: Sovereign Virtue: The Theory and Practice of Equality. Capítulo 12. Cambridge, Harvard UP, 2002. Para uma análise empírica dos resultados da ação afirmativa em admissão a cursos superiors nos EUA, veja-se William G. Bowen and Derek Bok: The Shape of the River: Long-term Consequences of Considering Race in College and University Admissions. Princeton, Princeton UP, 2000. 
dessa história constitucional ocorre com a Independência. O princípio da igualdade no direito constitucional brasileiro nasceu com a missão de alinhar-se retoricamente ao incipiente e impreciso mas já prestigioso movimento republicano e democrático moderno, enquanto acomodava na sua prática constitucional o modelo de sociedade estamental e escravocrata do período colonial. Assim, no Império a primeira constituição brasileira tomava lado com a moda de monarquias constitucionais enxertadas com parlamentos representativos e com direitos individuais clássicos reservados na sua integralidade apenas a nacionais homens, brancos, adultos e proprietários. Em seu $8^{\circ}$ Título - "Das Disposições Geraes, e Garantias dos Direitos Civis, e Politicos dos Cidadãos Brazileiros" - a constituição imperial fazia do princípio da igualdade perante a lei um dos elementos do sistema constitucional da "inviolabilidade dos Direitos Civis, e Politicos dos Cidadãos Brazileiros, que tem por base a liberdade, a segurança individual, e a propriedade" (artigo 179). O inciso XIII do artigo 179 dizia: “A Lei será igual para todos, quer proteja, quer castigue, e recompensará em proporção dos merecimentos de cada um." 16

O episódio seguinte veio com a República. No âmbito das mudanças que levaram à Abolição da Escravatura em 1888 e ao movimento militar que fundou a República no ano seguinte, a primeira constituição republicana de 1891 dizia no $\S 2^{\circ}$ do artigo 72 que "todos são iguais perante a lei." Mas tanto nesta fase como na anterior a distância entre a retórica legislativa e as práticas constitucionais era de dimensões continentais. Dando um salto de quase um século no qual pouco se acrescentou, o último episódio é exatamente o de expansão e detalhamento do princípio da igualdade na constituição de 1988. A atual constituição, logo no preâmbulo, elenca a igualdade entre os "valores supremos de uma sociedade fraterna, pluralista e sem preconceitos, fundada na harmonia social." O artigo $3^{\circ}$ lista como "objetivos fundamentais da República" o "construir uma sociedade livre, justa e solidária," a erradicação da "pobreza e [d]a marginalização," a redução das "desigualdades sociais e regionais" e por fim a promoção do "bem de todos, sem preconceitos de origem, raça, sexo, cor, idade e quaisquer outras formas de discriminação." É assim, como valor supremo e como objetivo fundamental, que a igualdade faz sua entrada no texto constitucional. Ao longo de todo o texto da constituição, a igualdade reaparece como direito protegido contra seu arquiopositor, a discriminação, e como princípio regulador das

16 Note-se a menção ao mérito, tema que será abordado abaixo. 
relações de trabalho, das licitações públicas, das relações entre estados no cenário internacional, das diferenças entre regiões e entes federativos no cenário nacional, das relações maritais no âmbito doméstico, no acesso e permanência no ensino público, no tratamento a deficientes, no tratamento a empresas nacionais, nos processos e procedimentos penais etc. Diante de tal abundância legislativa, seria de esperar-se que ela recebesse envergadura teórica, destilação doutrinária e gerasse energia prática. Nada disso ocorre.

O que garante, entretanto, a consistência dessa com as demais fases da experiência constitucional brasileira são dois fatores: (I) a distância invariavelmente guardada entre a retórica da constituição e a doutrina constitucional apensada a ela, de um lado, e a prática constitucional, de outro lado; (II) e as limitação e imprecisão da retórica constitucional vigente, qualquer que fosse seu grau de eficácia. As explicações para a ação desses fatores tão intimamente intertecidos no contexto do Brasil contemporâneo seriam necessariamente alongadas e complexas. De importância central, porém, para qualquer esforço explicativo é compreender o impacto da falta de uma teoria constitucional da igualdade que concentre e dirija tanto o discurso quanto a prática constitucional para uma experiência constitucional da igualdade que reflita os ideais republicanos e democráticos subjacentes a ela.

Na experiência americana, a Suprema Corte, a despeito de todo o seu primitivismo moral, veio a ser um dos catalizadores intelectuais e políticos e por décadas o principal agente social da equal protection; no Brasil, o Supremo Tribunal Federal fala de um "postulado republicano que repele privilégios e não tolera discriminações" e de "essencial igualdade" 17 entre indivíduos; proclama, mal-informado cientificamente, que "[n]ão há diferenças biológicas entre os seres humanos [; n]a essência são todos iguais" e que portanto a "divisão dos seres humanos em raças resulta de um processo de conteúdo meramente político-social;" fala na "[p]revalência dos princípios da dignidade da pessoa humana e da igualdade jurídica;" e que "[j]amais podem se apagar da memória dos povos que se pretendam justos os atos repulsivos do passado que permitiram e incentivaram o ódio entre iguais por motivos raciais de torpeza inominável."18 A análise da retórica desses julgados - feita da perspectiva da experiência constitucional que ela de fato reflete e ajuda a manter - a

18 HC 82424 / RS, DJ 19-03-2004. 
revela como descasada de profunda e sistemática análise conceitual, inconsciente da forma de vida que o texto e os ideais que abraça direcionam a instituir e carente de ambição social. ${ }^{19}$ Ao longo de sua história, o Supremo Tribunal Federal desenvolveu cultura e hábito institucional de deferência aos poderes da hora e um fetichismo do procedimentalismo, onde o mais alto prêmio esteve sempre na imaginação de tangentes processuais como rotas de fuga do enfrentamento substantivo das questöes que lhes são trazidas a examinar ${ }^{20}$.

A doutrina constitucional brasileira tem, quanto à questão da igualdade e no que sei, o exato mesmo desempenho de sua corte constitucional. ${ }^{21}$ Os comentários doutrinários ao texto constitucional pouco, quando muito, dizem da experiência constitucional como tal e permanecem no paradigma oitocentista no que respeita ao acabamento conceitual da igualdade como princípio regulativo de forma de vida coletiva. Tal como na jurisprudência do Supremo Tribunal, a doutrina constitucional brasileira ignora o mais importante significado dos ideais republicano-democráticos modernos e suas demandas de igualdade. Em suma, o discurso constitucional no Brasil sofre, no tema da igualdade, de dois defeitos: é incapaz de dar vida aos princípios que abraça; além do que e de qualquer forma, abraça princípios mutilados, estancados num momento de consciência relativamente ainda mais incipiente do que o atual do significado dos ideais e programas emancipatórios alojados no centro gravitacional da modernidade.

Como se explicar o fracasso da experiência constitucional brasileira? O que fazer?

${ }^{19}$ Não obstante a sensibilidade para a questão que se detecta, por exemplo, em opinião do seu então presidente em Marco Aurélio M. de F. Mello: "Ótica Constitucional - A Igualdade e as Ações Afirmativas.” 33, Revista Trimestral de Direito Público, páginas 5-11 (2001).

20 Veja-se, como evidência eloqüente do que se afirma, a seleção de "julgamentos históricos" do Supremo Tribunal Federal em http://www.stf.gov.br/jurisprudencia/julghistoricos/

${ }^{21}$ Consulte-se, quanto à constituição do Império, o também autor do anteprojeto da lei de 1871 (Ventre Livre) José Antônio Pimenta Bueno: Direito Público Brasileiro e Análise da Constituição do Império. Rio de Janeiro, Ministério da Justiça e Negócios Interiores, 1857; para a primeira constituição do período pós-imperial veja-se seu autor, Rui Barbosa, em seu República: Teoria e Prática. Petrópolis, Vozes/Câmara dos Deputados, 1978; ainda quanto a constituição de 1891, veja-se João U. C. Barbalho: op. cit.; para as constituições de 1937, 1946, 1967 e 1967 com emenda de 1969, vejam-se os respectivos Comentários (que se repetem quase que completamente, com exceção do primeiro) de Pontes de Miranda, que a despeito do seu rústico positivismo cientificista apresenta, a que sei, a mais profunda análise da igualdade no constitucionalismo brasileiro. A monografia clássica da última parte do século passado é aquela já mencionada acima de autoria de Celso A. B. de Mello. 


\subsubsection{Excurso Sobre a Escravidão em Joaquim Nabuco}

O Brasil vive em oblívio da escravidão ${ }^{22}$, embora tanto de sua sociedade, cultura, instituições e práticas sociais cotidianas ainda exibam tão marcadamente o caráter inconfundível do molde escravagista em que foram forjados. Feita de infinitas trivialidades e banalidades interrompidas por tragédias periódicas, a experiência constitucional brasileira tem na escravidão e seus ecos sociais ao longo do tempo o seu maior escândalo. Como introdução a esse escândalo faz-se agora uma breve digressão sobre a crítica social e cultural desfechada por Joaquim Nabuco contra o Brasil oitocentista - "[e]stá assim uma nação livre, filha da Revolução e dos Direitos do Homem, obriga[da] a empregar os seus juízes, a sua polícia, se preciso for o seu Exército e a sua Armada, para forçar homens, mulheres e crianças a trabalhar noite e dia, sem salário" (97) 23 - a partir da perspectiva abolicionista. A digressão promete contribuir com valioso discernimento à tentativa de oferecer uma resposta ainda que incompleta à primeira das duas questões com que se concluiu a seção anterior.

$\mathrm{O}$ gênio de Nabuco consistiu exatamente no que faltou e falta à elite intelectual da experiência constitucional brasileira: ele entendeu o problema da escravidão como um problema da forma de vida coletiva que o Brasil elegera nos períodos da colônia e império. ${ }^{24} \mathrm{~A}$ ele não escapou a natureza de "fatalidade moral" da escravidão, uma fatalidade que arruinava a todos, escravos e não escravos. Com a escravidão e os traços de caráter que alimentou, dizia Nabuco, a "sociedade nacional existe [...] no grau de molusco, isto é, sem vértebras nem individualização." (143) Teve ele ainda a sensibilidade de perceber a desgraça pessoal que para os libertos e os "ingênuos" consistia em viverem como negros em uma sociedade em que negros eram escravos. E, por fim, mostrou Nabuco lucidez quanto aos efeitos duradouros da escravidão caso não se procedesse, com a libertação, a um programa extenso, intenso e profundo de transformação do caráter da sociedade brasileira como um todo. Que tal programa nunca haja sido implementado é quando menos um dos elementos fundamentais para qualquer explicação que se queira dar para a falência da experiência constitucional brasileira da igualdade.

\footnotetext{
22 A despeito de uma importante tradição historiográfica nas universidades.

23 Joaquim Nabuco: O Abolicionosmo. Petrópolis, Vozes, 1988 (1883). Idem para as demais citações de Nabuco.

${ }^{24}$ Para compreensão da escravidão nos EUA como tal veja-se Tocqueville: $o p$. cit. Livro I, Parte II, Capítulo 10.
} 
Nabuco enxergou, na tradição oitocentista de interpelação abrangente da sociedade como problema, "a escravidão como sistema social e econômico" (46), como uma "mancha de Caim, que o Brasil traz na fronte" (23) e que levava a uma "degradação sistemática da natureza humana." (23) Falando dos partidos políticos - "partidos que são apenas sociedades cooperativas de colocação ou de seguro contra a miséria" (138) - no simulacro de democracia representativa do império, ele criticava o status quo político que vivia em permanente compromisso com a escravatura advertindo que "o dever de elevar os escravos a homens precede a toda arquitetura democrática." (31) Insistia que "a raça negra nos deu um povo [...]; ela construiu o nosso país. [...] Suprima-se mentalmente essa raça e o seu trabalho, e o Brasil não será, na sua maior parte, senão um território deserto, quando muito um segundo Paraguai, guarani e jesuítico." (37) E a ele não convencia o pendor da cultura brasileira para a autopiedade, a bajulação das elites, nem a retórica inconseqüente em forma de caricatura de boas intenções enunciadas de um púlpito qualquer. Sob uma epígrafe de Eusébio de Queiroz - "[a]s nações como os homens devem muito prezar a sua reputação" - Nabuco prosseguia na acusação que desfechava contra a sociedade brasileira: "[o] crime nacional não podia ter sido mais escandaloso, e a reparação não começou ainda. No processo do Brasil um milhão de testemunhas hão de levantar-se contra nós, dos sertões da África, do fundo do oceano, dos barracões da praia, dos cemitérios das fazendas, e esse depoimento mudo há de ser mil vezes mais valioso para a história do que todos os protestos de generosidade e nobreza d'alma da Nação inteira." (88)

À vista da condição humana do escravo, e em tom rousseauniano, ansiava ele que chegasse o momento da "pátria [...] alargar as suas fronteiras morais até [àquele] abranger." (41) 25 E no tom da dialética hegeliana da relação senhor-escravo revelava a clareza com que também via a condição humana do proprietário de escravos: "a emancipação não significa tão somente o termo da injustiça de que o escravo é mártir, mas também a eliminação simultânea dos dois tipos contrários, e no fundo os mesmos: o escravo e o senhor." (36)

Mas é sobretudo como dotador do caráter do Brasil como forma de vida coletiva que

25 Esta passagem o inscreve na tradição, de Rousseau a R. Rorty, que vê a moral como epifenômeno da empatia. 
a escravidão, assim como arruína economicamente o país, impossibilita o seu progresso material, corrompe-lhe o caráter, desmoraliza-lhe os elementos constitutivos, tira-lhe a energia e a resolução, rebaixa a política; habitua-o ao servilismo, impede a imigração, desonra o trabalho manual, retarda a aparição das indústrias, promove a bancarrota, desvia os capitais do seu curso natural, afasta as máquinas, excita o ódio entre classes, produz uma aparência ilusória de ordem, bem-estar e riqueza, a qual encobre os abismos de anarquia moral, de miséria e destruição, que do Norte ao Sul margeiam todo o nosso futuro. (91-92)

A miséria humana da escravidão - tragédia que brutaliza a espécie e embota seus potenciais de desenvolvimento moral, intelectual, afetivo e criativo - tem portanto um alcance estrutural para além dos milhões que engolfou diretamente na crueldade e humilhação cotidianos. Para Nabuco, a luta contra a escravidão implicava, portanto, uma dupla frente de batalha: no front imediato estava a libertação dos escravos; noutro, mais mediato, estava a combinada tarefa de reconstrução de toda uma forma de vida coletiva e das formas de personalidade humana que até então forjara. Sem uma vitória no front mediato que estirpasse a marca funesta da escravidão moderna, a vitória no front imediato da emancipação provaria ser vazia e condenaria o Brasil a viver permanentemente com a escravidão enquanto sonhava ser finalmente moderno. Quanto à parte estrutural das necessárias reformas, ele dizia que

[A] obra - de reparação, vergonha ou arrependimento, como a queiram chamar - da emancipação dos atuais escravos e seus filhos é apenas a tarefa imediata do Abolicionismo. Além dessa, há outra maior, a do futuro: a de apagar todos os efeitos de um regímen que, há três séculos, é uma escola de desmoralização e inércia, de servilismo e irresponsabilidade para a casta dos senhores [...]. Quando mesmo a emancipação total fosse decretada amanhã, a liquidação desse regímen daria lugar a uma série infinita de questões, que só poderiam ser resolvidas de acordo com os interesses vitais do país pelo mesmo espírito de justiça e humanidade que dá vida ao Abolicionismo. Depois que os últimos escravos houverem sido arrancados ao Poder sinistro que representa para a raça negra a maldição da cor, será ainda preciso desbastar, por meio de uma educação viril e séria, a lenta 
estratificação de trezentos anos de cativeiro, isto é, de despotismo, superstição e ignorância. O processo natural pelo qual a Escravidão fossilizou nos seus moldes a exuberante vitalidade do nosso povo durou todo o período do crescimento, e enquanto a Nação não tiver consciência de que lhe é indispensável adaptar à liberdade cada um dos aparelhos do seu organismo de que a escravidão se apropriou, a obra desta irá por diante, mesmo quando não haja mais escravos. (27)

Quanto à reforma do caráter mesmo daqueles imersos numa sociedade escravocrata Nabuco não foi nunca menos incisivo. Advogava ele uma reforma que buscasse a personalidade humana e seus atributos morais na sua mais densa e profunda cidadela existencial, vez que "[e]ssa reforma individual, de nós mesmos, do nosso caráter, [...] é o único meio de suprimir efetivamente a escravidão da constituição social. A emancipação dos escravos é portanto apenas o começo de um Rinnovamento [...]." (169-170)

Mas para angústia sua ele não encontrava no Brasil de seu tempo forças para expungir os traços da escravidão "como principal elemento da nossa constituição." (142) Sua desesperança quanto a esse aspecto baseava-se na percepção de que numa sociedade minada moralmente pela escravidão moderna, apenas do poder político organizado poderia advir seu fim e a criação e implementação de um programa de reimaginação do modus vivendi até então escravocrata. Mas a sociedade escrava não podava apenas seu povo, a sua elite política era, ora encabeçada, ora intimidada, ora comprada pela retardatária e profundamente escravocrata classe dos proprietários rurais de Minas Gerais, Rio de Janeiro e São Paulo, confirmando que "[a]s soluções patrióticas de nossos estadistas só têm o defeito de serem póstumas." 26

Nabuco tinha, por fim, a precisa percepção do quanto "[a] senzala e a escola são pólos que se repelem.” (137) Já próximo do final de seu livro apresentou uma pequena parábola que ao Brasil serve bem ainda hoje

Dois meninos nasceram na mesma noite [...] nessa fazenda cujo regímen se pretende conservar: um é senhor do outro. [...] O senhor está sendo objeto de uma educação esmerada; o escravo 
está crescendo na senzala. [...] Quem negará que essas duas crianças, uma educada para grandes coisas, outra embrutecida para o cativeiro, representam duas correntes sociais que já não correm paralelas $[. .$.$] mas se encaminham para um ponto dado$ em nossa história na qual devem forçosamente confundir-se? Pois bem, o Abolicionismo o que pretende é que essas duas correntes nao se movam uma para a outra mecanicamente, por causa do declive que encontram; mas espontaneamente, em virtude de uma afinidade nacional consciente. [...I] sto é, que um e outro sejam arrancados a essa fatalidade brasileira - a escravidão - que moralmente arruína ambos. (160-161)

Em sua parábola Nabuco deixa o Brasil onde o encontramos hoje: assombrado pela inércia da ignorância, da miséria e de uma insidiosa e persistente subordinação de semi-estamentos, que é legado direto de uma escravidão contra a qual apenas a batalha mais imediata foi ganha, a da emancipação. Das batalhas das reformas do modus vivendi escravocrata, e do tipo de caráter humano que nele floresce, o Brasil desertou. A condição do negro no Brasil contemporâneo reflete uma avassaladora progressão que tem como ponto de partida o contexto escravagista. Tome-se, como exemplo desse lento e inaudível escorregar para fora da escravidão, o tratamento dispensado aos negros libertados nos termos na lei de 1885 27, a chamada Lei dos Sexagenários, que instituía, em substituição à lei do Ventre Livre de 1871, o fim paulatino da escravidão no Brasil através de combinação de incentivo à alforria voluntária e libertação obrigatória por idade. No esquema legislativo de 1885, aqueles alforriados geravam para seus ex-proprietários direito de indenização pela fazenda pública e à "usufruição dos serviços dos libertos por tempo de 5 anos" (Art. 3ํㅡ, §3, alínea $\mathrm{C}$ ), que seriam remunerados com gratificação "arbitrada pelo exsenhor com aprovação do Juiz de Órfãos” (§4). Já os escravos libertados pela idade sexagenária estavam "obrigados, a título de indenização pela sua alforria, a prestar serviços a seus ex-senhores pelo espaço de três anos" (§10); e quando findado o período indenizatório continuariam eles "em companhia de seus ex-senhores" que usufruiriam dos "serviços compatíveis

27 Veja-se o parecer de Rui Barbosa ao anteprojeto Dantas em seu Emancipação dos Escravos. Rio de Janeiro, Fundação Casa de Rui Barbosa. Para uma reconstrução dos debates legislativos à época veja-se Joseli M. N. Mendonça: Entre as Mãos e os Anéis. Campinas, Editora da Unicamp, 1999. 
com as forças deles, salvo se preferirem obter em outra parte os meios de subsistência, e os Juizes de Órfãos os julgarem capazes de o fazer" (§13). Há mais: "domicílio obrigatório por tempo de cinco anos [...n]o município onde tiver sido alforriado" (§14) e no caso de se ausentar de seu domicílio obrigatório, "será considerado vagabundo e apreendido pela Polícia para ser empregado em trabalhos públicos ou colônias agrícolas" (§15); "qualquer liberto encontrado sem ocupação será obrigado a empregar-se ou contratar seus serviços no prazo que lhe for marcado pela Polícia $(\S 17)$ [...] terminado o prazo, sem que o liberto mostre ter cumprido a determinação da Polícia, será por esta enviado ao Juiz de Órfãos, que o constrangerá a celebrar contrato de locação de serviços, sob pena de 15 dias de prisão com trabalho e de ser enviado para alguma colônia agrícola no caso de reincidência" (§18); essas colônias agrícolas seriam, por sua vez, "regidas com disciplina militar."

Tem-se assim que a transição de uma sociedade baseada na escravidão para uma sociedade pós-escravocrata foi feita, no Brasil, sob a binária lógica jurídica do incentivo ou compensação econômica dos proprietários de escravos e da regulação hierarquizante e englobante da vida dos libertos através da disciplina jurídica de suas relações de trabalho pós-escravagismo. Criminalização, paternalização ${ }^{28}$, disciplinação e "educação" para a liberdade via relação subordinante de trabalho, jurisdição do setor da magistratura encarregado daqueles com capitio diminutio; a saída dos negros da escravidão para a liberdade reproduziu um complexo prático-jurídico-cultural próprio da escravidão e caracterizado pela dependência, pela humilhação e pela total ingerência sobre e disciplina dos mais escônditos e pessoais dos eventos biográficos de cada indivíduo. De um lado, então, o incentivo econômico para o proprietário combinado com o dever de indenização ou compensação recaindo sobre os libertos e ingênuos; de outro lado, uma "educação" para a liberdade via relação subordinante de trabalho que englobava todos os aspectos da vida do empregado, que era agora "de casa". A transição da sociedade escravocrata brasileira para o período pós-escravagismo arregimentou um conjunto de políticas ativas e omissivas, diretas e indiretas claramente identificáveis que garantiu a continuidade da substância sob uma outra forma: de uma sociedade estamental baseada na objetificação e propriedade de membros do estamento escravo para

28 Mesmo de um abolicionista de primeira ordem como Rui Barbosa, vide o parecer mencionado na nota anterior. 
um regime de criação regulada de uma classe social subalterna, subeducada e subempregada a cujo pertencimento foi avassaladoramente determinado pela cor. O efeito da combinação desses fatores com uma concepção delgada de igualdade como status normativo que sobrevive até hoje, foi a criação e o concomitante e sempre renovado engessamento de um semi-estamento, ainda hoje maciçamente demarcado pela cor, sobre o qual recai generalizados juízo de inferioridade e expectativa social de subordinação.

Os sinais dessa dupla lógica jurídica são ainda onipresentes e renovados constantemente. ${ }^{29}$ Hoje, portanto, o cenário deixado pela deserção da sociedade brasileira inclui milhões de negros que ocupam um quase-estamento vastamente constituído de guardadores-de-carro, empregadas domésticas, meninos-de-quintal, população carcerária, servidores no tráfico de drogas, e de presas de instituições que vendem redenção postmortem e lendas de regeneração e sucesso pessoal através da promessa de uma intermediação autorizada junto a poderes extramundanos. Mas a marca de uma sociedade escravocrata pode ser vista em todo lugar. Procurando detectar a expressão jurídica da progressiva modernização das sociedades ocidentais, Henry Maine ${ }^{30}$ propôs as categorias de "status" e "contrato" como candidatas. Dizia ele que

[i]f then we employ Status, agreeably with the usage of the best writers, to signify these personal conditions only, and avoid applying the term to such conditions as are the immediate or remote result of agreement, we may say that the movement of the progressive societies has hitherto been a movement from Status to Contract.

No Brasil essa transição deu-se, no que diz respeito às relações de trabalho, de modo a preservar elementos de coerção e dependência característicos das sociedades cuja divisão do trabalho fundava-se no status. Tem-se então o fenômeno do "trabalho escravo" ou da "escravidão por

${ }^{29}$ Que um exemplo baste: enquanto escrevo estas linhas (setembro de 2004) um jornal noticia a proposta de deputado federal do Partido dos Trabalhadores que, enquanto relator na Comissão de Finanças e Tributação anuncia que proporá um redutor do imposto de renda de pessoas físicas para gastos com empregados domésticos, na imensa maioria negros empregados por não-negros.

30 Henry Sumner Maine: Ancient Law. New Brunswick, Transaction Publishers, 2001. Capítulo 5. 
dívida" no Brasil contemporâneo. ${ }^{31} \mathrm{O}$ fim relutante da escravidão no Brasil encontrou sua expressão por excelência numa igualdade pro forma, que entre outras coisas explicava a retórica pedestre e fazia os efeitos antirepublicano-democráticos característicos de sua experiência constitucional. Enquanto isso, o Brasil continua a sonhar que é moderno, republicano e democrático.

\section{Analítica da Igualdade}

Procede-se agora à tarefa de dissecar o conceito de igualdade através de seu contrário. A analítica da igualdade a perscruta em termos de seus sujeitos, de seu objeto, da penetração social dos efeitos de sua violação, da periodicidade de seu reparo, e do alcance das intervenções públicas reparadoras quando de sua violação. A estratégia eleita é aquela que vê a igualdade a partir de sua face mais visível, ou seja: de sua violação. $O$ aparato analítico aqui proposto gera, como se verá, tipos abstratos possíveis de igualdade/desigualdade. O objetivo é sempre o de dar substância conceitual a um valor que integra dorsalmente dois importantes ideais emancipatórios modernos. Passemos, então, às categorias artificialmente isoladas de violação da igualdade:

A - Igualdade com respeito às vítimas de sua violação: (I) indi víduos/grupos com base em sua condição como tal, (II) indivíduos/grupos com base em característica permanente ou especial e transitória, ou (III) indivíduos/grupos com base em circunstâncias permanentes ou especiais e transitórias. Onde 'I' reflete um tipo de desigualdade direcionada a ou resultante de alguma característica associada ao sentido de identidade, própria de indivíduos ou grupos; 'II' reflete um tipo de desigualdade direcionada a indivíduos ou grupos devido a características que, embora não necessariamente definidoras de sua identidade, de um modo contextualmente relevante, são dotadas de uma visibilidade social que inspira ou dispara a violação da igualdade; já 'III', por sua vez, refere-se a um tipo de desigualdade associada a um conjunto de circunstâncias que colhem indivíduos ou grupos em razão da posição destes em relação a tais circunstâncias, independentemente de sua identidade como grupo ou indivíduo (I) ou

${ }^{31}$ Para apreensão do fenômeno do ponto de vista de seus participantes veja-se o estudo de Ricardo Rezende Figueira: Pisando Fora da Própria Sombra: A Escravidão por Dívida no Brasil Contemporâneo. Rio de Janeiro, Civilização Brasileira, 2004. 
de características suas (II).

B - Igualdade com respeito aos objetos de sua violação: (I) igual dade de P, (II) igualdade de oportunidade para alcançar P, e (III) igualdade diante de $P$. Enquanto 'I' se refere à posse ou propriedade desigual de um bem, seja ele qual for, 'II' descreve uma chance relativa desigual que indivíduos ou grupos têm de alcançar um determinado bem, onde a desigualdade de chance se mostra resultante de uma desigualdade de oportunidade para participar na cadeia causal que traz ou pode trazer a seus participantes tal bem, e 'III' reflete uma situação onde indivíduos ou grupos recebem uma porção desigual de um bem como, por exemplo, legislação.

C - Igualdade com respeito à penetração social de sua violação: (I) direcionada ou (II) geral. O importante aqui é definir a violação da igualdade de acordo com o efeito final da violação. Assim, no caso de 'I', o efeito da violação resta limitado à parte dos indivíduos ou a um subgrupo de indentificáveis indivíduos ou grupos que partilham identidade, característica ou circunstância, ao passo que em 'II' a violação estende seus efeitos a todos os que partilham da mesma identidade, característica, ou circunstância.

D - Igualdade com relação à periodicidade do ajuste requerido por sua violação: (I) ajuste, ou ação corretiva, no início de uma certa relação ou processo social, (II) em certos momentos durante uma relação ou processo social, (III) ao final de uma relação ou processo social, ou (IV) em várias combinações de, 'I,' 'II' e 'III'. Onde 'I' define uma situação onde a correção de uma dada desigualdade só pode ser implementada - e a limitação aqui pode ser tanto moral como prática como uma combinação de ambas - através de intervenção corretiva no ponto inicial da relação ou processo social que a gera, ao passo que 'II', a meio caminho num contínuo, permite intervenção corretiva durante a relação ou processo social, rearranjando assim a posição relativa de indivíduos ou grupos antes que o resultado final da interação seja produzido. Em 'III', a extremidade final do contínuo, só há intervenção - quer por razões práticas ou morais ou ambas - ao término da interação a fim de se ajustar a divisão dos seus produtos de acordo com um critério qualquer de igualdade. Finalmente, 'IV' representa intervenções corretivas possíveis no princípio, em meio e ao final da interação social que revela o potencial de gerar desigualdade.

E' - Igualdade com respeito ao alcance da intervenção pública ou privada corretiva relativa aos sujeitos: (I) específica e (II) geral. Outra distinção a se fazer é entre a correção por agentes e políticas públicas ou por agentes e iniciativas privadas de desigualdade restrita em seus efeitos 
às partes de uma relação ou processo social específicos, como é o caso em 'I', e aquela cujos efeitos se estendem a todos os indivíduos ou grupos que partilham, com as partes direta, imediata ou mais visivelmente afetadas, alguma característica ou identidade ou circunstância relevantes, como é o caso em 'II'.

E” - Igualdade com respeito ao alcance da intervenção pública - e eventualmente privada - corretiva relativa às circunstâncias: (I) pon tuais e (II) estruturais. A distinção a ser feita aqui é entre um tipo de intervenção dos poderes públicos que, como é o caso em 'I', corrige desigualdades através da manipulação limitada de manifestações exemplares das relações ou processos sociais que as geram, porém sem estancá-los enquanto geradores gerais de desigualdade, e um outro tipo de intervenção, como em 'II', que busca definitivamente reformar aspectos estruturais das relações e processos sociais vistos como causadores da desigualdade de modo a dar remédio geral a aspectos causadores também gerais.

Note-se que a analítica da igualdade aqui proposta não a interroga quanto a uma possível tipologia dos agentes causadores. Uma teoria da igualdade como princípio regulador da concreção de ideais republicanodemocráticos em formas de vida coletiva deve estar sempre em guarda contra novos agentes e meios de geração de desigualdades que assaltem as bases dessas mesmas formas de vida as quais procura constituir e regular. Segue adiante uma analítica da discriminação, que parece ser empreendimento mais útil e gozando de mais sólidas bases teóricas do que seria o caso de uma tipologia dos agentes da desigualdade.

\section{Analítica da Discriminação}

Nossas mentes são, por natureza e aprendizado, discriminadoras; nossos sistemas jurídicos são, por experiência e como requer a complexidade das sociedades modernas, necessariamente discriminadores e classificadores. Entretanto, há um tipo de discriminação que falha em pôrse em linha com os requisitos de justificação impostos pelos princípios políticos, morais e jurídicos que ocupam o centro mais denso das idéias republicanas e democráticas modernas, incluindo seu corolário e base igualitária. Esse tipo de discriminação, como fenômeno social sob a jurisdição da opinião moral-político-jurídica, é então manifestação funesta do que de outra forma é uma valiosa faculdade humana e competência pragmático-institucional das ordens jurídicas. Para entender a natureza e capturar a diversidade da discriminação maligna propõe-se a seguinte tipolo- 
gia: discriminação ativa e discriminação omissiva, discriminação comportamental e discriminação estrutural e discriminação deslocadora e discriminação furtiva.

A- O primeiro par enfatiza o tipo de envolvimento dos agentes da discriminação, quem quer que sejam esses, onde (I) Discriminação ativa é aquela em que ação ou conjunto de ações apresenta tendência a causar, intencionalmente ou não, (i) vedação ou dificuldade expressiva e evitável de acesso de pessoas ou coletividades a bens e oportunidades ou (ii) uma hierarquia entre indivíduos e grupos com base em valoração assimétrica de características individuais ou coletivas consideradas proeminentes pelos agentes ativos da discriminação. (II) Discriminação omissi $v a$ é aquela em que a aquiescência dos agentes da discriminação - em ignorância, cumplicidade refletida ou em um híbrido qualquer de ambos com 'i' ou com 'ii' tem potência concausal de desigualdade.

B- O segundo par procura distingüir a sutileza da causação envolvida na discriminação. (I) Discriminação comportamental refere-se ao tipo de discriminação em que os efeitos identificados com 'i' ou 'ii' podem ser traçados de volta a comportamento suficientemente causador de indivíduos e grupos identificáveis. (II) Discriminação estrutural captura o tipo de discriminação em que os efeitos associados a 'i' e 'ii' são causados por intricado emaranhado de práticas sociais, instituições, fórmulas culturais e outros fatores anônimos ou de difícil personificação. Para empregar uma analogia geométrica, a discriminação comportamental é horizontal enquanto a discriminação estrutural seria vertical e circundante, de acordo com a posição dos discriminados e dos agentes mediúnicos da discriminação em relação a seus fatores causantes. Note-se que os dois primeiros pares submergem em suas categorias a questão da mens rea, da intenção e motivação dos agentes da discriminação. A razão para tanto é simples: boas ou inocentes intenções não redimem a discriminação maligna do juízo que dela faz uma teoria da igualdade informada pelos ideais republicanodemocrático.

C- Por fim, o terceiro par diz da forma como os discriminados experimentam a discriminação. Nesse caso, (I) discriminação deslocadora aponta para os casos em que os discriminados, ao experimentarem os efeitos associados a 'i' e 'ii', vêem deslocados seu sentido de valor-próprio, sua confiança nos seus atributos pessoais, a percepção de sua estação social, sua força reivindicativa ou sua capacidade de resistência. Estamos aqui no universo da crueldade, da humilhação, da desesperança, da subordinação pervasiva, da perda do compasso de pertencimento social, da hie- 
rarquização e da dominação sociais. Já a (II) discriminação furtiva alude àqueles casos em que os efeitos associados a 'i’ e 'ii' são experimentados pelos discriminados de modo quer a naturalizá-los quer a legitimá-los como corolários de formações sociais cujas premissas ideológicas são extensamente subscritas mesmo por eles.

A sociedade brasileira foi inoculada com todas as manifestações de discriminação aqui tipificadas que, conforme momento e contexto, apresentam-se em diferentes combinações e ênfases. O que agrava o entorpecimento com o qual esta sociedade reage a elas quando vitimizam negros e aborígenes é a tendência - prístina mas em grande medida reforçada a partir da década de trinta do século passado com a publicação de Casa Grande \& Senzala - às formas omissiva, estrutural e furtiva de discriminação que, juntas, explicam o poder da inércia da ignorância e da miséria transgeracional intrafamiliar em função da cor e da etnia no Brasil.

\section{Analítica do Mérito}

A combinação moderna da igualdade de status moral e jurídico como valor e do ideal de uma não intimidada Bildung criou uma tensão ${ }^{32}$ que na história das idéias vem sendo enfrentada através do recurso à idéia de mérito. Nessa história intelectual ao mérito pessoal cabe, juntamente com a sorte, justificar diferenças de propriedade e acesso a bens e oportunidades nas sociedades democrático-republicanas. Por ser assim um protagonista da cena moderna, o conceito de mérito requer também esclarecimento. Fundamental é precisar o conceito do que se deve entender por mérito pessoal e as implicações morais de seu peso relativo como fator na alocação, entre indivíduos ou entre grupos, de bens e oportunidades nas formas de vida republicana e democrática.

Há dois sentidos em que mérito ou merecimento são geralmente entendidos, um instrumental e outro pessoal:

A- No sentido instrumental, mérito costuma ser uma medida do

\footnotetext{
32 Tensão que se detecta, por exemplo, no comentário de Pimenta Bueno ao direito de igualdade na constituição imperial: "A natureza, circunstâncias ou educação, ou ambas, criam e constituem os homens com desenvolvimento de suas faculdades físicas, intelectuais e morais por modos diferentes. Suas idéias, aptidões, paixões, gostos, variam e estabelecem uma desigualdade que ninguém pode destruir, e que é mesmo um princípio providencial. [...] embora porém exista essa desigualdade importante e incontestável, por outro lado é fora de dúvida que todos os homens têm a mesma origem e destino, ou fim idêntico. Todos têm o mesmo direito de exigir que os outros respeitem os seus direitos, de alegar que uns não nasceram para escravos, nem outros para senhores [...]." (op. cit.: p. 411-412).
} 
grau de relevantes predicados de que dispõe um indivíduo para realizar tarefas ou receber treinamento para realizá-las. A instrumentalidade desse entendimento do que seja mérito está na relação entre uma dada finalidade e a eficiência relativa das capacidades individuais para ela disponibilizados. Assim é que se fala, por exemplo, de mérito como sendo a posse por cada indivíduo dos conhecimentos e habilidades mais eficientes para o exercício de uma profissão ou para receber treinamento para o posterior exercício de uma profissão qualquer. Essa concepção de mérito é intensamente prospectiva e pode ser capturada pelo conceito mérito como capa citação específica. Para adiantar exemplo adiante explorado em mais detalhe, tal concepção é a que preside sobre a retórica explicadora e justificadora do modelo de distribuição de oportunidades educacionais no Brasil; e o faz com o agravante de confundir a capacitação específica para receber treinamento com vista ao exercício de profissões pela capacitação específica para o efetivo exercício profissional, quando é claro que este não reflete necessariamente aquele. Se assim o fosse, o processo educativo para o exercício de profissões não seria capaz de agregar qualquer valor educacional. Bem ao contrário, a experiência indica que com frequiência aqueles que terminam o processo de educação superior melhor capacitados para o exercício profissional não estavam entre aqueles inicialmente considerados os mais capacitados para receber essa educação. A razão para o fenômeno parece simples: o modo como uma bem mais rica variedade de atributos pessoais - mais rica do que aqueles considerados nos exames vestibulares de acesso - interage com qualidades da educação superior provida.

B- A outra concepção de mérito é a que o vê como reconhecimento do grau de um conjunto de virtudes pessoais - mérito como virtude. Nessa concepção mérito pessoal significa desempenho em relação às oportunidades oferecidas e aos desafios encontrados ao longo da vida. O importante é saber o que indivíduos foram capazes de realizar com os bens e oportunidades que a sociedade e a família colocaram à sua disposição. A crítica feita dessa perspectiva à concepção instrumental do mérito é de que se elementos impessoais como a natureza e a extensão das oportunidades oferecidas são também pesadamente computadas na equação do mérito, esse deixa logicamente de ser uma conquista ou atributo intensamente pessoal; e se o mérito pessoal não é - junto à sorte intelectual - fator determinante do acesso a bens e oportunidades, não há que se falar em legitimação de desigualdades pela virtude. Assim é que numa sociedade democrática e republicana que abomina a cristalização de padrões distributivos de bens e oportunidades com base na cor, sexo, gênero, local de 
habitação ou filiação a religiões organizadas etc.; enfim, numa sociedade com tal sensibilidade moral e ideário emancipatório, mérito pessoal como virtude deve ser o critério preponderante na distribuição das escassas vagas de acesso aos cursos que formarão a elite mais intelectualizada desta sociedade.

Além disso, no exemplo do acesso à educação superior de qualidade, não é apenas pela sua superioridade moral e democrática que o mérito como virtude recomenda-se: a vantagem de eficiência comparativa do mérito como virtude sobre o mérito como capacitação específica está em que aquele é ao mesmo tempo retrospectivo e intensamente prospectivo, enquanto que este é apenas, como se apontou, prospectivo. Explico: a excelência demonstrada no aproveitamento das oportunidades educacionais recebidas no passado, mesmo que medíocres estas, é o mais seguro indicador do quanto se pode esperar do aproveitamento da oportunidade de vir a receber educação superior de qualidade para a capacitação profissional. No Brasil, como adiante se discutirá com mais detalhe, o atual sistema de admissão aos melhores cursos superiores representa um monopólio de facto dos privilegiados pela sociedade através da aplicação de mensuradores, de toda forma defeituosos, de mérito como capacitação específica para receber instrução superior. Tal sistema captura apenas, no melhor dos cenários, uma pálida e indireta indicação do mérito como capacitação para o exercício de profissões e é absolutamente incapaz, mesmo no mais bem-sucedido dos casos, de aferir o mérito como virtude. $\mathrm{O}$ que ele mede ainda que imperfeitamente é um conjunto limitado de conhecimentos e habilidades considerados desejáveis para o aproveitamento da oportunidade educacional para capacitação para o exercício de profissões. O sistema falha, para ir mais diretamente ao ponto, em mensurar o que candidatas foram capazes de alcançar com as oportunidades que tiveram; vestibulares não distinguem no resultado de cada vestibulando os pesos relativos, de um lado, das oportunidades que tiveram e, de outro, do mérito de seu aproveitamento delas. Naturalmente que salta aos olhos que tais conhecimentos e habilidades estão em função, entre outras coisas, das oportunidades educacionais proporcionadas pela sociedade e pelas famílias aos indivíduos, gerando assim um círculo permanente que redunda num padrão distributivo estrangeiro ao princípio da igualdade.

Visto da perspectiva que sugiro como sendo a própria às sociedades democráticas, juízos comparativos sobre mérito como virtude de indivíduos devem idealmente descontar as diferenças sistemáticas e injustificáveis no acesso a bens e oportunidades não só de desempenho 
meritório mas também de obtenção - através, por exemplo, da família ou do Estado - do equipamento de burilação e incremento de potenciais com que cada indivíduo é inatamente dotado. É evidente que tal desconto ou neutralização ideal de fatores impessoais na avaliação comparativa de méritos pessoais é tarefa fadada a acentuada complexidade e sempre limitado sucesso. Mas evidente também o é que esforços imaginativos, dispostos a aprender e a experimentar e afincadamente consistentes e persistentes devem ser intentados pelas sociedades de ideário e práticas democráticorepublicanas.

\section{Igualdade Republicano-Democrática}

Retorno agora à questão com que comecei: que tipo de igualdade os ideais republicanos e democráticos, tal como aterrissados nas idealizações modernas de formas emancipadoras de vida coletiva, exigem? Submeto que a igualdade da democracia e da república é aquela que impede desigualdades que dêem sobrevida ou possam reinstaurar elementos de um Estado autoritário e patrimonial, de uma sociedade civil estamentária e de um tipo de solidariedade social predominantemente intragrupal ou intraclasse. A analítica da igualdade, da discriminação e do mérito é assim apenas um instrumento a serviço de um certo princípio regulativo de modus vivendi. É o substrato dos ideais democrático e republicano tal como reconstruídos acima que provê a derradeira direção nos vários contextos - práticos, doutrinários e teóricos - em que toma forma e corpo a experiência constitucional das comunidades políticas. Tendo em mente sempre que o arcabouço moral de onde proveio e provém a crítica da sociedade do Ancient Régime tem no seu cerne uma visão dos indivíduos como titulares de uma dignidade não instrumentalizável ${ }^{33}$ e uma visão da espécie como lançada ao futuro que se quer fazer progresso.

Arregimentando a analítica da igualdade sob a bandeira da igualdade democrático-republicana proponho que: sempre que for o caso de a desigualdade em igualdade de $X$, igualdade de oportunidade para alcançar $X$ ou igualdade diante de $X$, seja ela direcionada ou geral, atingir indivíduos ou grupos de modo a indicar a sobrevida ou a reinstauração de formas de vida coletiva que frustram a idéia de um elenco expansível de potenciais benignos para a espécie e da exploração intensa, por cada indi-

33 Formulação canônica dessa visão aparece em Kant: Fundamentação da Metafísica dos Costumes. 
víduo, de cada um desses potenciais; sempre que for esse o caso e a origem ou contribuição causal da desigualdade puder ser traçada até casos de discriminação ativa ou omissiva, comportamental ou estrutural, deslocadora ou furtiva, à necessária forma de ajuste - quer seja ajuste, ou ação corre tiva, no início de uma certa relação ou processo, em certos momentos durante uma relação ou processo, ao final de uma relação ou processo ou em várias combinações destes - por agentes públicos ou privados, quer sejam, conforme o caso, de efeitos e alcance específico ou geral e pontual ou estrutural, é requerida pelo ideal republicano-democrático e deve ser parte constitutiva da experiência constitucional, no seu dia-a-dia, de formas de vida organizadas à luz desse ideal.

\section{A IGUALDADE E O CASO DA AÇÃO AFIRMATIVA}

\section{A Natureza do Problema}

A mobilidade intrafamiliar transgeracional ascendente de educação e renda no Brasil é minúscula, no que reflete tendência mundial. A inércia da parca educação e da pobreza entre gerações da mesma família marca, com cicatriz brutal, a sociedade brasileira. A essa ferida soma-se o caráter onipresente - profundo e velado por resilientes cacoetes culturais e processos sociais - da desigualdade dos negros e aborígenes. Acesso à melhor educação superior oferece momento privilegiado para flagrar alguns dos efeitos da inércia e do preconceito. Mas oferece também uma oportunidade de escolha fundamental: ou reforça-se o ciclo inercial e de preconceito que se arrasta desde o início de uma sociedade ainda sob o signo da escravidão ou procura-se rompê-lo. Que não tenha havido ao longo da história republicana e democrática um conjunto de políticas públicas corretivas agressivas, criativas e consistentes voltadas a romper o ciclo da inércia da miséria e da ignorância e do preconceito é epifenômeno da ainda mais generalizada incapacidade da sociedade de gerar e manter debate sofisticado e profundo sobre o tema e de experimentar o que deveria ser visceral e universal indignação. Como fragmento da experienência constitucional brasileira, o regime de distribuição de bens educacionais falha no teste da igualdade. Estamos, então, diante de tema vocacionado a ser interpelado por meio de uma teoria constitucional da igualdade republicano-democrática.

Está claro que, no que diz respeito ao acesso à educação supe- 
rior, o país já possui em operação desde o início de sua história universitária um sistema monopolístico de facto de cotas de acesso a bens e oportunidades educacionais. $\mathrm{O}$ atual sistema de facto de cotas na admissão aos melhores cursos superiores no Brasil reserva quase o total das vagas existentes àqueles beneficiados por um padrão de distribuição de bens e oportunidades educacionais que não sobrevive a escrutínio de justiça e decência humana. ${ }^{34} \mathrm{O}$ atual foco sobre ação afirmativa para acesso a cursos superiores no Brasil é portanto bem-vindo e necessário. Padece o foco, porém, de debate; trata-se de foco distorcido ao qual falta clareza. A incompreensão que contamina o incipiente debate está relacionada tanto ao limitado entendimento da própria natureza do problema que se está a tentar remediar quanto ao que está dramaticamente em jogo. Essa incompreensão é ainda em muito exponenciada pelas justificativas apresentadas tanto para as iniciativas legislativas até então tomadas como para as primeiras reações, mesmo aquelas favoráveis a essas iniciativas legislativas, do

\footnotetext{
34 Eis aqui uma fábula cuja analogia com o Brasil contemporâneo serve de teste para a sensibilidade republicano-democrática do leitor: imagine que se recrutassem dois adolescentes com equivalente e inato talento para a mecânica e a pilotagem de automóveis e a eles se provesse, ao longo dos anos correspondentes à sua educação primária e secundária, manuais de mecânica e peças de automóveis de diferentes qualidade e tipo. Para aquele que recebera o mais capenga dos manuais foram dadas ainda as respectivas peças de um automóvel de passeio, enquanto que para o outro, recebedor do mais acurado e completo manual, as respectivas peças de um automóvel de corrida. A eles foi ainda dito que ao atingirem a idade de 18 anos teriam que disputar uma corrida com os carros que construíram, corrida essa que decidiria qual deles teria acesso às melhores escolas superiores de pilotagem e mecânica do país. Assim é que, passados os anos, nas hora e data marcadas, lá estavam os candidatos, um pilotando um automóvel de passeio cujas dificuldades de montagem incluiu contar com o deficiente manual de que dispunha e o outro pilotando um modelo de competição para cuja montagem contou com o melhor manual disponível. Dada a partida e transcorrida a corrida sem incidentes, eis que o piloto-mecânico na direção do automóvel de corrida alcança primeiro a linha de chegada. Questionada sobre a justiça do critério de seleção escolhido, a sociedade responde que a justiça do critério estaria garantida pelas idênticas condições da competição, já que os pilotos-mecânicos tiveram a oportunidade de provar, por mérito pessoal, sua capacidade para a mecânica e pilotagem através de uma corrida na mesma pista, com largada simultânea e com idênticos pontos de partida e chegada. Satisfeitos todos de que a distribuição de oportunidades de educação superior em mecânica e pilotagem seja feita, em sua sociedade, por cota única destinada àqueles que ao longo da vida receberam os melhores manuais e peças disponíveis, em uníssono a família do vencedor, seus amigos, os organizadores da prova e a sociedade confortavelmente apontam o mérito pessoal do primeiro colocado como fator explicador e justificador da decisão sobre a alocação da oportunidade educacional em questão. Para análise da posição moral dos pais e guardiães de estudantes estruturalmente beneficiados, veja-se Adam Swift: How not to be a Hypocrite: School Choice for the Morally Perplexed Parent. London, RoutledgeFalmer, 2003; para radicalização do argumento defendido neste livro, veja-se Colin M. Macleod: "The Puzzle of Parental Partiality." 2, Theory and Research in Education, páginas 309-321 (2003).
} 
Judiciário e do Ministério Público. A incompreensão que contamina o debate frustrando seu objetivo social de esclarecimento da forma de vida coletiva em que se vive e suas respectivas opções alastra-se virulentamente tanto no plano conceitual como no da utilização dos dados sociais disponíveis e das propostas para enfrentamento dos desafios associados ao problema.

Três tarefas parecem-me então concomitantemente urgentes: (i) o esclarecimento de alguns dos principais fatores geradores da incompreensão da questão; (ii) a crítica, nos termos de uma teoria da igualdade, do atual sistema de cotas de facto reservadas em monopólio àqueles que a sociedade brasileira, na distribuição que faz de bens e oportunidades, beneficia de modo estruturalmente sistemático e discriminatório daqueles que exclui; (iii) e, por fim, se o sistema de monopólio de cotas sempre existiu no Brasil, a tarefa inadiável que se apresenta é agir com urgência para desbaratá-lo, e nesse caso o que precisamos mesmo é da combinação sempre transformadora de conhecimento, indignação, energia ativa e idéias. Em jogo está a decência da República e o modus vivendi em que os potenciais da espécie para o progresso intelectual, moral e criativo e para a vida afetiva são nutridos ou embotados.

\section{Distribuição e Acesso}

Outro fator que deve informar a análise do problema é a especificidade da distribuição no Brasil de bens e oportunidades educacionais em função da cor e da etnia. Na sociedade brasileira, o acesso a bens e oportunidades de um modo geral e a bens e oportunidades educacionais em particular está associado, dentre outros fatores, à renda, família, geografia, educação, cor e etnia. Entretanto, os fatores negritude e etnia aborígene operaram historicamente e ainda operam intensamente no interior de cada um dos demais fatores. Assim é que no Norte e Nordeste o acesso a tais oportunidades varia inclementemente em relação à cor e à etnia. E em todo o território brasileiro a posição relativa dentro de cada camada de renda ou classe profissional obedece também a diferenças de cor e etnia, sendo tais diferenças, por sua vez, critério decisivo no acesso às oportunidades educacionais dentro de suas fronteiras. O ciclo vicioso se aperfeiçoa e completa: vivendo na mesma região, abraçando a mesma profissão e ocupando a mesma camada de renda, aqueles em algum ponto do diapasão da negritude ou do pertencimento a uma das etnias aborígenes têm menos acesso aos bens e oportunidades educacionais do que aqueles noutro espectro de cor ou de outra 
etnia. É assim imperativo que se leve em consideração no debate sobre ação afirmativa ou, talvez mais acuradamente, no debate sobre como implodir a cota de facto já existente, o fenômeno da sistêmica desigualdade na distribuição de oportunidades e bens educacionais em função da cor e da etnia.

Mas o que faz a discriminação no acesso a bens e oportunidades em função da cor e etnia fenômeno tão persistente e pervasivo entre os brasileiros? O breve excurso sobre a escravidão em Joaquim Nabuco ofereceu uma explicação socioteorética para esse fenômeno. Está claro que a inércia da pouca, em quantidade e qualidade, educação e da pobreza regride transgeracionalmente aos sistemas escravocrata e colonizador que vitimizaram brutalmente negros e aborígenes. As formas de organização da vida coletiva sucedâneas da experiência colonizadora e escravocrata engendraram, por sua vez, uma série de causas legais e socioeconômicas e de fórmulas culturais que operaram e operam sucessiva e concomitantemente para discriminar contra aqueles no diapasão da negritude e da aboriginidade. Desvendá-los a todos em seus microcósmicos e macrocósmicos detalhes é tarefa que vem sendo enfrentada, com marcantes sucessos e frustrantes limitações, pelas Ciências Sociais e pela Historiografia. Urgente, não obstante, para o esboçante debate atual é reconhecer a natureza familiar transgeracional da tendência replicadora da carência de oportunidades educacionais e da pobreza e sua delimitação pela cor e etnia. Tal tendência por si só, e mesmo que na ausência de todas as informações de que se dispõe, evidenciaria a operação na sociedade de um conjunto de pontos ou nós estruturais discriminatórios - a combinação das formas estruturais e furtivas, sobretudo, de discriminação - ao longo da vida de aborígenes e negros. Desatá-los é luta a ser travada também concomitante e sucessivamente, e com corajosa disposição, numa miríade de fronts.

$\mathrm{O}$ acesso à educação superior de qualidade é front privilegiado da resistência à discriminação e da resultante desigualdade antidemocráticorepublicana. No centro estratégico do aparato da discriminação estrutural na sociedade brasileira está o processo de discriminação sistemática que conflui no momento de seleção para as escassas vagas nos cursos minimamente sérios de formação superior. Esse processo ocupa o centro estratégico da discriminação na medida em que nele convergem elementos retrospectivos e prospectivos. ${ }^{35}$ Retrospectivo porque sobre este momento de

35 Não se trata de aplicação da dicotomia entre a justeza do processo distributivo e a justeza do quinhão ao final auferido por cada beneficiário. Para uma distinção entre as duas respectivivas concepções de justiça - "end-result principle" e "historical principle" -, veja-se Robert Nozick: Anarchy, State, and Utopia. New York, Basic Books, 1974. Páginas 153-155. 
seleção inevitavelmente deságuam o processo tanto de replicação estrutural transgeracional de padrões de acesso a bens e oportunidades educacionais como, no plano mais imediatamente biográfico e intrageracional, os acidentes e incidentes de inserção familiar, profissional e regional influenciadores das oportunidades pessoais de cada candidato ${ }^{36}$. Aí, nesse instante seletivo, o impacto biográfico das várias formas de discriminação que agem sinergética e sistematicamente é amplificado e pode ser visto mesmo pelos olhos mais desavisados ou decididos a não enxergar. Já o fator prospectivo do centro estratégico discriminatório da seleção a cursos superiores está nas chances de mobilidade social ascendente e florescimento pessoal associados a este estágio do processo educacional. O nó do acesso à educação superior é, a um só tempo, também estratégico do ponto de vista da eficiência na luta contra a discriminação, bem como uma exigência moral que pesa sobre uma sociedade que se recusa a bloquear, pela cor e etnia, acesso aos bens e oportunidades que coletivamente produz e cria, e que têm tão amplificado impacto sobre a expansão coletiva e o aproveitamento pessoal dos potenciais humanos. Se o princípio da igualdade republicano-democrática deve ser operativo na experiência constitucional de formas de vida com aspiração a tais programas emancipatórios, então a discriminação estrutural que é desnuda nos modos de alocação de acesso a cursos superiores é inimiga a ser constitucionalmente combatida. Assim sendo, submeter o sistema brasileiro de cotas de facto de acesso à educação superior a desimpedidos e profundos escrutínio moral, análise de estratégia e eficiência e iniciativas reajustadoras é tarefa central a um constitucionalismo republicano e democrático. E em relação à retrospectividade e prospectividade desse momento seletivo, apenas uma reconcepção do conceito vulgar de mérito-como-capacitação, agente que é da discriminação furtiva, promete responsividade moral e responsabilidade com eficácia.

Concomitante à compreensão dos processos produtores e reprodutores da desigualdade perversa e às iniciativas corretoras desses, é necessário de pronto renunciar às formas de discurso retribalizador da "política de identidade". Se o preço a pagar-se pelos esforços agudos e persistentes para desatar os nós ensejadores, mantenedores e acobertadores da discriminação pela cor e etnia for abrir as portas para processos de medievalização da sociedade brasileira, o preço terá sido o próprio ideal republicano-democrático. Entendese, entretanto, que tal renúncia à retribalização solapadora da solidariedade

${ }^{36}$ Em jogo está nada menos do que a esperança, material indispensável da educação. Veja-se discussão em David Halpin: Hope and Education: The Role of the Utopian Imagination. London, RoutledgeFalmer, 2003. 
geral é tanto mais necessária quanto mais difícil em face do desnorteio causado pela combinação da experiência da discriminação deslocadora e a tomada de consciência da discriminaçãofurtiva com a crítica à idéia da "democracia racial" e o subseqüiente clamor pela assunção de uma consciência grupal como oposto simétrico aos efeitos da discriminação deslocadora. A forma de vida que o retribalismo promete trai a promessa de decência social e progressos afetivo, moral, criativo e intelectual que devem inspirar a crítica mais profunda e consequiente da discriminação. Além de gravemente confundir, numa recaída herderiana ${ }^{37}$, o que há de valioso na diferença, o discurso retribalizador pela etnia comete o duplo equívoco do fetichismo da diferença e da mistificação de suas vítimas. Equívoco esse que mais cedo ou mais tarde volta-se, na forma da espada da objetificação e da alienação da política de identidades, sobre a cabeça dos próprios discriminados.

\section{Proposta}

A condição dos negros e dos aborígenes no Brasil caracteriza desigualdade antidemocrático-republicana e requer intervenção corretiva com status não de permissivo mais de exigência constitucional. A abolição do monopólio sobre as vagas nos melhores cursos superiores deve fazer parte, vez que ocupa a posição de um dos pilares da reprodução estrutural da desigualdade, de um conjunto de iniciativas reajustadoras pontuais, onde possível e urgente, e estruturais. Como medida corretiva pontual e, no caso, específica proponho, a título de experimentação, a criação de sistemas de contra-cotas de facto que resgatem todos aqueles que, com potencial para o curso superior aferido pelo grau de mérito-como-virtude, foram, ao longo de suas vidas e em função de processos sociais orientados à sua cor ou etnia, sistematicamente discriminados por sua sociedade na alocação de bens e oportunidades educacionais.

Um sistema de ação corretiva - afirmativa - através do desenvolvimento de um regime de pluralização das cotas poderia tomar como ponto de partida programas já adotados, mesmo que capengamente, no Brasil, por Estados e pelo Governo Federal para vagas em cursos superiores ou na administração pública. Um critério experimental seria defender contra o monopólio da cota-de-fato das elites ou dos relativamente privilegiados uma parcela das vagas nos melhores cursos para negros e aborí-

37 Veja-se Johan G. von Herder: "This Too a Philosophy of History for the Formation of Humanity.” Em Philosophical Writtings. Cambridge, Cambridge University Press, 2002. 
genes provenientes de famílias pobres. $\mathrm{O}$ alvo flexível dessa parcela seria a representação, no corpo discente, de semelhante proporção na população relevante de negros e aborígenes. Tomar como ponto experimental de partida outro critério para estabelecimento da percentagem da contra-cota seria sugerir que a distribuição na espécie humana de mérito-como-virtude obedece a linhas de cor ou etnia.

Preocupação legítima em relação a essa proposta é aquela relativa ao possível estigma social a recair sobre aqueles eventualmente poupados, através de um tal sistema, da discriminação do sistema monopolístico da cota de facto dos privilegiados. A experiência do Direito moderno tem mostrado que benefícios são mesmo freqüentemente acompanhados quer pela mistificação, especialmente quando vistos como vítimas, quer pela estigmatização dos beneficiados, num perverso processo que tende a cristalizar as próprias posições sociais das quais se pretende dar saída àqueles lá mantidos reféns pelo modus vivendi a que pertencem. Mas esquivarse da operação constitucional corretiva por causa desses efeitos equivaleria a punir vítimas certas da discriminação por ousarem dela escapar. Ceder a essa preocupação seria render o ideal de igualdade republicana e democrática a uma estrutura que sustenta sua prática discriminatória com chantagens e ameaças; seria responder com embotamento a um desafio frontal ao caráter moral da república democrática e da concepção da promessa de dignidade humana que esta encerra. Seria uma outra deserção das reformas que deveriam ter acompanhado o fim da Escravidão. Porém, a natureza imoral da chantagem não diminui sua realidade e a experiência informará a imaginação de meios de arrefecê-la até que desapareça.

De início sugeriria então variação do modelo que adota, nos exames de seleção, fórmula de cálculo final das médias que compensasse a diferença de acesso a bens e oportunidades educacionais com base em informações sobre séries históricas de admissão de pobres, negros, aborígenes, daqueles que cresceram em famílias cujos responsáveis não concluíram curso superior e daqueles egressos de escolas públicas ${ }^{38}$. Explico. Tome-se, digamos, tais dados referentes àqueles que hajam prestado exame de admissão para determinada instituição nos últimos vinte anos. Pergunte-se então que peso deveria ter sido dado a esses fatores para que na média desses anos o alvo de admissão de negros e aborígenes fosse atingido. $\mathrm{O}$ valor assim encontrado deveria ser empregado a favor de negros e aborígenes

38 Reconheço agradecido a contribuição das discussões sobre esse aspecto da proposta que mantive com Antônio Oliveira-dos-Santos. 
pobres no cálculo das médias dos exames de admissão para o ano seguinte. A cada ano a série histórica abandonaria o primeiro ano da série anterior e incorporaria dados relativos ao ano imediatamente precedente. Tal medida teria a vantagem subsidiária de funcionar como medidor do grau de distribuição dos bens e oportunidades educacionais no futuro. Se em algum momento a série histórica, que seria renovada ano-a-ano, mostrasse que nenhum ajuste no cálculo das médias seria necessário para admitir-se o número almejado de candidatas negras e aborígenes, essa ação corretiva seria dispensada no ano seguinte e, eventualmente, permanentemente.

\section{Reflexões Finais sobre Ações Corretivas}

Um abrandamento do atual sistema de facto de cota única através da criação de uma espécie de cotas-plurais para aborígenes e negros de modo a mensurar o mérito pessoal de cada candidato advindo desses grupos, descontadas as desigualdades de oportunidades educacionais a que foram submetidos, não é e nem deve ser, entretanto, medida corretora única - trata-se de iniciativa pontual e específica contra uma das manifestações de problema estrutural e geral. Desatar um nó não é desatá-los a todos. Mas falhar em desatar cada um daqueles nós que porventura se tornam visíveis e vulneráveis a desatamento constitui omissão moral e constitucional, com profundas consequiências sobre a forma de vida coletiva que se leva.

É preciso reconhecer, portanto, que a quebra do monopólio de facto das cotas de admissão aos cursos superiores pelas elites privilegiadas por uma sociedade profundamente injusta é instrumento imperfeito na execução e limitado no alcance. Trata-se apenas de aproximação, e portanto de compromisso inevitavelmente pragmático, a um sistema de mensuração do mérito pessoal que idealmente descontasse e neutralizasse padrões e estratégias perversas de subordinação, distribuição, hierarquia e injustiça sociais. Este artigo, e assim o deve ser a política de cotas-plurais que ele defende, procura traçar a rota da luta pela redução das causas do sofrimento e humilhação de modo a evitar, de um lado, a percepção de que essas causas podem ser reduzidas a questões de status econômico e, de outro lado, a rua sem saída das formas de política de identidade.

Vagas em cursos superiores e oportunidades de as obter são bens de natureza pública, produzidos ao longo do tempo pelo esforço coletivo de agentes, agências financiadoras, instituições governamentais e da sociedade civil e fundos públicos e privados. É dever de toda sociedade sustentada no valor da igualdade, tal como desdobrado nas seções anteriores, 
impedir a perversidade consistente em concentrar um bem educacional publicamente produzido no seu âmbito nas mãos de grupos sociais que detêm, por força de discriminação longeva pela cor e etnia, privilegiado e monopolístico acesso a ele. Tal medida reflete compromisso com a prática democrática, com a rejeição das formas personalizadas e estruturais de crueldade, e com a sempiterna aspiração ao progresso humano. A luta por sua implementação deve ser a luta daqueles que abraçam esses valores e aspiram por uma sociedade que não fruste, por razões de cor e etnia, possibilidades de auto-afirmação e florescimento pessoais e da espécie.

\section{CONCLUSÃO}

Os lineamentos para uma teoria constitucional da igualdade aqui desenvolvidos começaram por traçar os contornos gerais dos ideais do cerne dos quais o conceito de igualdade deve extrair seu sentido. Propôsse a seguir que a igualdade assim entendida deveria funcionar como princípio inspirador e regulador da experiência constitucional de formas de vida coletiva organizadas à luz daqueles mesmos ideais de república e democracia. A questão sobre a mesa era: que tipo e grau de desigualdade deve-se tolerar que a distinção entre pessoas e grupos crie? As analíticas da igualdade, da discriminação e do mérito procuraram, então, forjar lentes que pudessem capturar mesmo as manifestações menos visíveis de sabotagem da igualdade através de processos sociais discriminatórios e enrijecedores de estações sociais. Como contexto de concretização exemplificadora da teoria jurídico-política, densamente prescritiva que o artigo expõe, discutiu-se com brevidade a escravidão e a questão do acesso de negros e aborígenes a cursos superiores de qualidade.

Em cada um dos momentos do artigo, a direção para uma teoria constitucional da igualdade aqui proposta assumiu uma dupla dependência. De um lado, a dependência de uma visão da modernidade e do lugar nela ocupado pelos ideais crítico-emancipatórios da democracia e da república. De outro lado, uma visão do que está em jogo para cada um de nós, para as formas de associação e de vida comum que buscamos e para a espécie como um todo em suas possibilidades de progresso. A proposta partilha assim, necessariamente, do destino de suas dependências.

PAULO DAFLON BARROZO é doutorando em

Direito pela Harvard University. 